\title{
Resilience and adaptability of rice terrace social-ecological systems: a case study of a local community's perception in Banaue, Philippines
}

\author{
$\underline{\text { Adam C. Castonguay }}^{1,2}$, Benjamin Burkhard $^{1,3}$, Felix Müller $^{1}, \underline{\text { Finbarr G. Horgan }}^{4}$ and Josef Settele $^{5,6}$
}

\begin{abstract}
The social-ecological systems of rice terraces across Southeast Asia are the result of centuries of long-term interactions between human communities and their surrounding ecosystems. Processes and structures in these systems have evolved to provide a diversity of ecosystem services and benefits to human societies. However, as Southeast Asian countries experience rapid economic growth and related land-use changes, the remaining extensive rice cultivation systems are increasingly under pressure. We investigated the long-term development of ecosystem services and the adaptive capacity of the social-ecological system of rice terrace landscapes using a case study of Banaue (Ifugao Province, Northern-Luzon, Philippines). A set of indicators was used to describe and assess changes in the social-ecological state of the study system. The resilience of the rice terraces and the human communities that maintain them was examined by comparing the current state of the system with results from the literature. Our findings indicate that, although the social-ecological system has not yet shifted to an alternative state, pressures are increasing and some cultural ecosystem services have already been lost.
\end{abstract}

Key Words: adaptive capacity; agroecosystems; complex adaptive systems; ecosystem services; human well-being; Ifugao Rice Terraces

\section{INTRODUCTION}

The rice terraces of Southeast Asia are highly complex systems supporting several ecosystem processes and functions, and supplying various ecosystem services that benefit not only local human populations but also domestic and international tourists. Besides the production of rice for local communities, rice terraces are at the center of a complex of agroecosystems that supply additional provisioning ecosystem services, such as fish and snails (Lu and Li 2006, Garaway et al. 2013), and forest goods, such as fruits and medicinal plants (Hayama 2003, Gu et al. 2012), as well as important regulating services, for instance, flood mitigation, water-resource conservation, erosion reduction, and heat mitigation (Agus et al. 2006, Burkhard et al. 2015). Additionally, cultural services provided by rice terraces include religious identity (Lansing 1987, Lansing and Kremer 1993), tourism (Lorenzen and Lorenzen 2010, Truong et al. 2014), and national pride (Nozawa et al. 2008). For instance, the rice terraces of Ifugao in the Philippines are nationally considered as the "eighth wonder of the world" (Dizon et al. 2012) and were described as an "irreplaceable treasure" in the Philippines by presidential decree in 1973 (Nozawa et al. 2008). Large parts of the terraces are included in the UNESCO World Heritage List (UNESCO 1996) and are among the Globally Important Agricultural Heritage Sites selected by the Food and Agriculture Organization of the United Nations (see Koohafkan and Cruz 2011).

However, the communities making a living from rice terraces face several challenges. Besides environmental disasters such as typhoons, landslides, and earthquakes, integration to the market economy and increasing trade have become drivers of change that bring new pressures to the system. Rice farmers are now increasingly exposed to the uncoordinated development of tourism (e.g., conversion of rice terraces for hotel or restaurant construction), the intentional or unintended introduction of invasive alien species (Martin et al. 1998), and applications of pesticides and inorganic fertilizers (Joshi et al. 2000, SITMo 2008). The inclusion of the Ifugao Rice Terraces in the List of World Heritage [sites] in Danger from 2001 to 2012 is a reminder of the pressures to which these areas are subject (UNESCO 2012).

Considering the fast changes caused by these new pressures, our aim was to assess the long-term development of rice terrace socialecological systems using Banaue in the Philippines as a case study. The study used an indicator-based survey to assess the state of the system and compared the results with previous work to investigate the system's resilience and adaptive capacity.

Resilience-related concepts stemmed from work on ecological resilience by Holling (1973) and have been discussed and further developed in a wide range of disciplines in the following decades (Folke 2006). Here we define resilience of a social-ecological system as the ability of the system to maintain its self-organization and functions following disturbances and to change to maintain the same function, structure, and feedbacks, i.e., to maintain its identity (after Folke et al. 2010). Several terms and concepts related to resilience have been developed to assess the properties of social-ecological systems. In this study, we also investigate adaptive capacity, which can be defined as the ability of the actors to cope with environmental changes and to influence the resilience of the system (Walker et al. 2004).

Based on the results from indicator-based surveys, we discuss linkages between the changes in ecosystem services and human well-being as the system evolves. The study also explores possible pathways and regime shifts for the case study area.

${ }^{1}$ University of Kiel, Institute for Natural Resource Conservation, Department of Ecosystem Management, ${ }^{2}$ Monash University, Department of Civil Engineering, ${ }^{3}$ Leibniz Centre for Agricultural Landscape Research (ZALF), ${ }^{4}$ Crop and Environmental Science Division, International Rice Research Institute, ${ }^{5}$ UFZ-Helmholtz Centre for Environmental Research, ${ }^{6}$ iDiv, German Centre for Integrative Biodiversity Research Halle-Jena-Leipzig 


\section{METHODS}

\section{Study area}

The study was conducted in the municipality of Banaue in the Ifugao Province on the island of Luzon, Philippines. The rice terraces in the region were thought to be approximately 2,000 years old (Barton 1919, Beyer 1955); however, more recent carbon dating of charcoal suggests that the terraces may have been established only after the arrival of the Spaniards to the Philippines Islands in the 16th century (Maher 1973, Acabado 2009). The rice terraces of the municipality of Banaue are situated at 780-1300 meters above sea level on the mid and lower slopes of the Gran Cordillera mountain range. The area surrounding Banaue is characterized by 7 wet months, with $300 \mathrm{~mm}$ or more of rainfall per month, and 5 dry months, with less than $150 \mathrm{~mm}$ of rainfall (Klotzbücher et al. 2015). These climatic conditions provide a dependable water source, but can also cause recurrent landslides (Araral 2013).

Locally developed rice varieties are principally of the Oryza sativa japonica subspecies as opposed to the indica subspecies that dominate in lowland rice production in the Philippines. These local varieties are described using the generic Ifugao word tinawon, meaning "yearly" in the local dialect (Conklin 1980). Tinawon is characteristic for its slow growth (6-9 months), reaching a height of $120-160 \mathrm{~cm}$, and can only be planted once a year (Roxas 1996). Despite the low yield, the tinawon varieties are cold tolerant and therefore produce more rice than lowland varieties at elevations higher than 1000 meters above sea level (Wackernagel 1985). Beside the tinawon, some indica varieties have been adapted for upland production. These are called pinidua in the region, meaning "second" in Ifugao (Conklin 1980). These varieties can be grown as a second crop after the tinawon and give generally higher yields than the traditional japonica varieties at elevation lower than 1000 meters above sea level (Wackernagel 1985). Overall, tinawons have traditionally constituted a large part of Banaue rice production, considering that roughly $80 \%$ of the varieties and $95 \%$ of rice yield in the Ifugao terraces are from tinawon varieties (Conklin 1980).

Banaue is mostly known for its extensive and steep rice terraces, contributing significantly to the cultural ecosystem service of landscape aesthetics. However, several other ecosystem services are supplied to inhabitants (and partly to tourists) by interacting landscape features, mainly the woodlots and swidden fields, but also by private gardens (Fig. 1). Located around the rice fields, the woodlots are owned by households (typically one to three woodlots per household) and are managed to provide firewood, fruits, lumber, and medicinal plants. Organic matter derived from the woodlots also provides a source of nutrients for the rice terraces (Conklin 1980, Serrano and Cadaweng 2005). Woodlots contribute to water regulation and provide an extended presence of water in the fields, thus preventing the layers of clay beneath the topsoil and behind the terrace dykes from cracking and eroding (Conklin 1980, Olofson 1983). Swidden fields have been an important part of the landscape, producing sweet potatoes that complemented rice as a staple food for households (Barton 1922). However, the use of swidden fields has declined in recent decades (Herzmann et al. 1998). Therefore, this study concentrates on rice paddies and woodlots as the two main agroecosystems of the social-ecological system in the municipality of Banaue.
Fig. 1. The Ifugao land use system. The rice paddies receive water-carried nutrients from ecosystems located above (black arrows). Woodlots are located around the rice terraces and hamlet, whereas public forests are located further away on the surrounding mountains. Swidden fields are cultivated on slopes too steep to make terraces. Harvested products are transferred to the hamlet (white arrows). The terrace shape of the rice paddies allows for the optimal use of nutrients and minimal erosion despite the steep slope (modified from Margraf and Voggesberger 1984; picture taken in Batad by the lead author [ACC] in 2013).

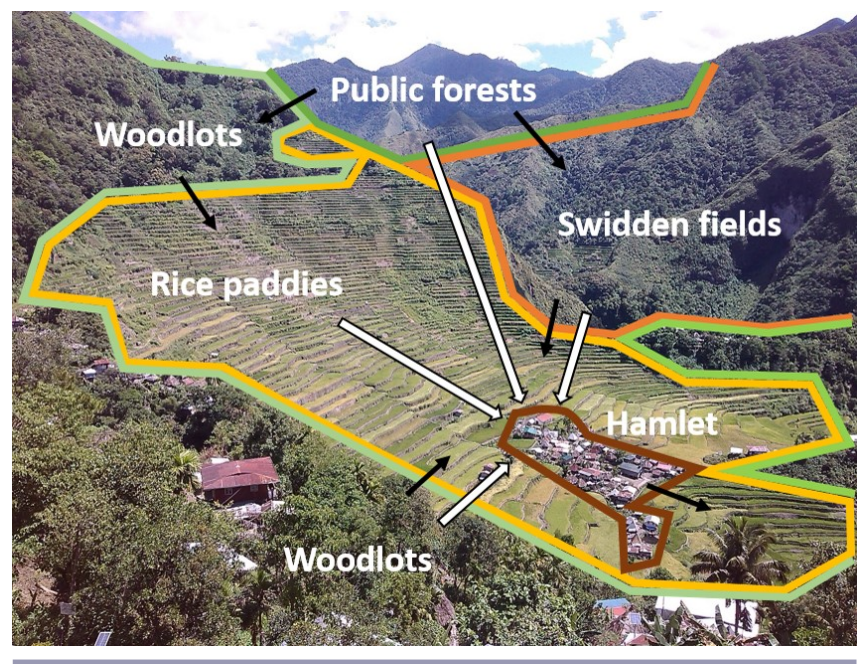

Cultural traditions of farmers in Banaue include rituals that were originally performed by a native priest, mumbaki, mostly for agricultural purposes as, for example, to ensure a good rice harvest or to reduce pest damage (Bulilan 2007). In general, up to 17 yearly rituals, which are based on religious and spiritual beliefs, were observed across the province of Ifugao (Conklin 1980). The land is inherited through a strict primogeniture custom: most of the property is passed to the oldest child, irrespective of gender, to avoid fragmentation of the rice fields (Conklin 1980).

Drastic changes to the terrace ecosystems have occurred over the last three decades. The invasive golden apple snail, or Pomacea canaliculata (Lamarck), was introduced to the Philippines from South America between 1982 and 1984 as a source of protein for human diets, but has become a major rice pest by feeding on the delicate rice seedlings soon after transplanting (Joshi et al. 2001). It reached the Ifugao rice terraces around 1990 (Martin et al. 1998). The colloquially named "giant earthworm" (Pheretima elongate) and the Asian swamp eel(Monopterus albus) are believed to have indirect effects on rice production by altering the hydrological regime in the terraces when their burrowing activities cause water seepage, which can lead to landslides (Barrion and Litsinger 1997, Joshi et al. 1999). The Tanezumi rat (Rattus tanezumi) and some species of birds, such as Lonchura spp. and Passer domesticus, can also have detrimental impacts on rice production (Joshi et al. 2000, Stuart et al. 2007). However, the actual impact, if any, from invasive species, e.g., in terms of yield loss, has yet to be quantified. Social pressures on the system include the integration of subsistence farming into the market 
economy, increasing tourism, and the conversion of indigenous polytheism to Christianity. All have had positive effects (e.g., increasing income) as well as negative effects (e.g., loss of cultural identity) on the social-ecological system (Guimbatan and Baguilat 2006, Bulilan 2007, Nozawa et al. 2008).

\section{Indicators of resilience and adaptive capacity}

A common assessment of resilience is to measure the recovery time, i.e., the time needed for the system to recover from a perturbation and to return to its domain of attraction after a disturbance (Pimm 1984, Veraart et al. 2012). This a posteriori method of measuring resilience can only be used once the system has returned to its initial state and fails to assess the capacity of the system to change and to maintain its identity. Considering the importance of social-ecological resilience for the livelihood of communities living from surrounding ecosystems, several authors have attempted to develop other measurement methods, either by developing numerical and spatial models (Fletcher and Hilbert 2007, Burkhard et al. 2011) or by identifying tipping points and anticipating critical transitions through early warning signals (Scheffer et al. 2012). These methods may be helpful in understanding trajectories of the system but require a large amount of data as input for the models. Another method to study the resilience of social-ecological systems is by developing multidisciplinary indicators (Van Oudenhoven et al. 2011, Cabell and Oelefse 2012, Bergamini et al. 2013). Although survey-based indicators may be subject to biases, this latter approach was chosen to study the social-ecological system of the Banaue rice terraces because of its applicability in subsistence farming systems in developing countries (Bélair et al. 2010).

To address both ecological and social subsystems, the driverspressure-state-impact-response (DPSIR; Burkhard and Müller 2008) model was linked with ecosystem structures (i.e., biophysical components), ecosystem services, and human wellbeing (the "ecosystem service cascade" after Haines-Young and Potschin 2010, Müller and Burkhard 2012, Spangenberg et al. 2014). By applying the coupled DPSIR-ecosystem services framework as the adaptive management cycle, we investigated whether farmers in Banaue have been resilient and able to recover from social and environmental changes that have been recorded in previous literature sources (see Data Collection section), and whether they have been able to adapt and improve their condition over time.

The selected indicators (Fig. 2) represent the different system stages within this conceptual model. The indicator invasive alien species represents one of the several pressures (see Change of Pressure section) on the system. Rice varieties and the diversity of edible plants were used to indicate ecosystem structures (see Change of State section). The indicator multifunctionality of forests refers to the variety of ecosystem services provided to humans by agroforestry in the woodlots, an important landscape component in Banaue (see Change of Impacts section). Further indicators of impacts in the system are food self-sufficiency, defined as the number of months for which farmers meet rice consumption needs through their own production rather than by buying food externally (Peljor and Minot 2010), and profitability, defined as the monetary benefits that result from the ecosystem services. Finally, traditional ecological practices and the inheritance system of primogeniture, i.e., right of succession belonging to the firstborn child, are some of the responses (see Change of Response section) that can mitigate the drivers of change, e.g., pest outbreaks and population growth, respectively. Indicators of drivers, e.g., changing climate or population growth, were omitted from this study to focus more fully on the response of the social-ecological system to pressures, the change of state, and impacts in the system.

Fig. 2. Adaptive management cycle of the Banaue socialecological system. The eight indicators used in this study (in italics) represent different stages of the drivers-pressure-stateimpact-response framework. Five of the indicators assess the dynamics of the "ecosystem services cascade" (state and impacts), two indicators represent responses, and one depicts pressures (adapted from Haines-Young and Potschin 2010, Müller and Burkhard 2012, Spangenberg et al. 2014).

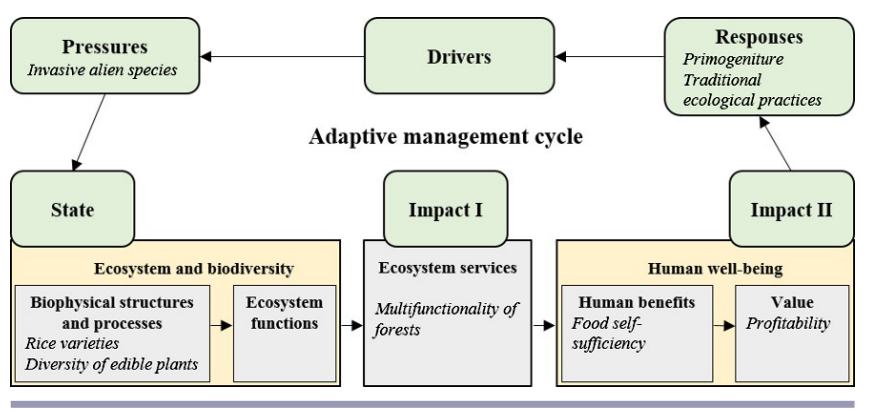

\section{Data collection}

Data were collected using a combination of qualitative and quantitative methods. Mixed methods have proven to be useful and even necessary in remote and data-poor regions, such as the Banaue municipality, to provide a first assessment of the socialecological background (Christie et al. 2012, Vollmer et al. 2015). The eight indicators shown in Table 1 were used to assess the changes between the baseline state and the current state of the social-ecological system. Information presented in the work of Barton (1919, 1922) and Conklin (1980, 1982) was used to attribute baseline values for each indicator. Barton and Conklin described the social-ecological system of Banaue (Conklin, 1980, 1982) and Ifugao (Barton 1919, 1922) in very similar ways, despite the amount of time between their research studies. Therefore, the system described in their publications was considered as the baseline state, to which the current state was compared.

A questionnaire was used to obtain data concerning the eight indicators that allowed us to assess the current state of the system. Surveys were conducted during a four-week period from May to June 2013. Semistructured interviews were carried out at 30 households with rice paddies in each of the following three areas of the municipality of Banaue: Barangay (smallest administrative unit in the Philippines) Batad, Barangay Bangaan, and the town of Banaue (Fig. 3), for a total of 90 respondents. These three Barangays were chosen to represent a gradient of tourism and other external influences. Banaue is the main tourist hub and is therefore more accessible than the surrounding villages. Batad also sees many tourists but is less accessible (during the study period the barangay could be reached by a one-hour walk from the next major road; in the meantime a new road made Batad more easily accessible). Bangaan is accessible by road but few 
Table 1. Baseline values of the indicators of the social-ecological system of Banaue rice terraces according to literature sources.

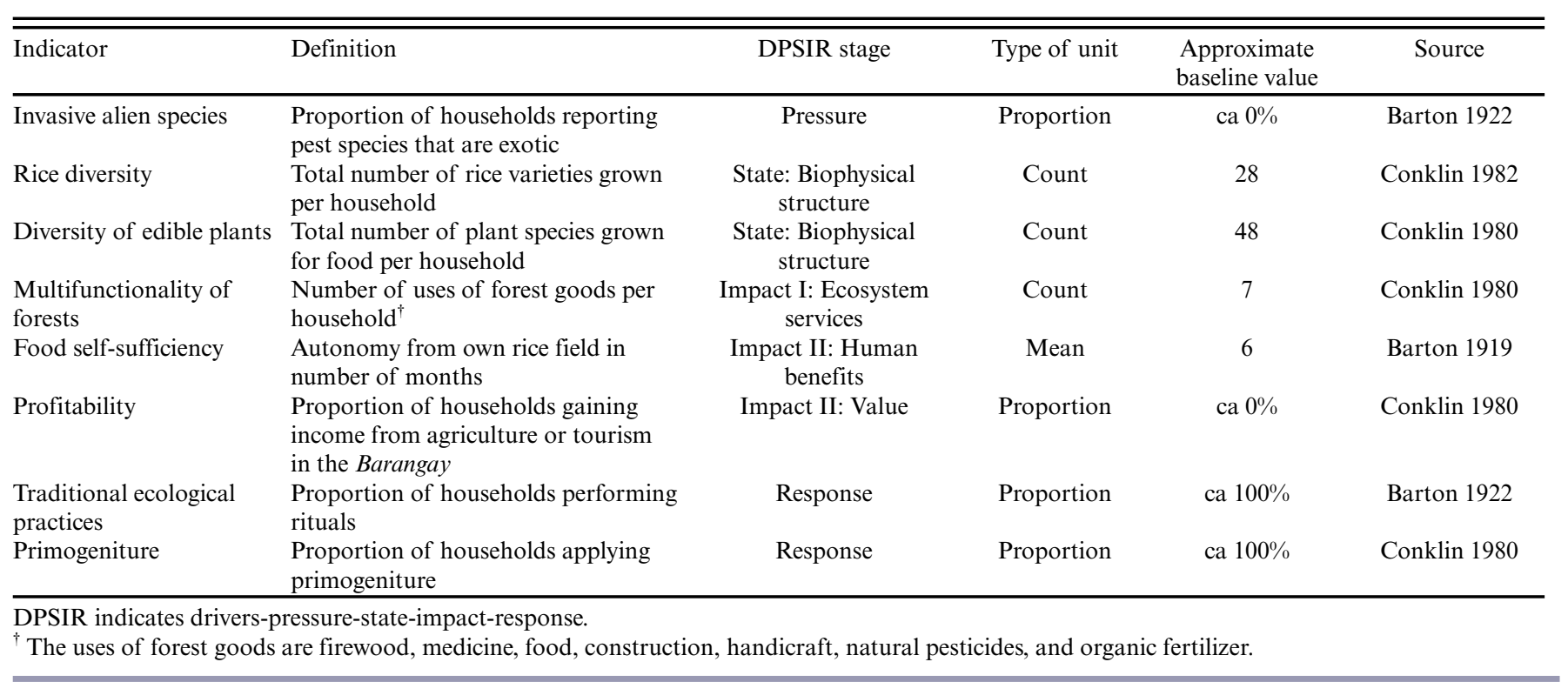

tourists visit the rice terraces. Most people, including farmers, can speak English in Banaue. Thus, the questionnaires were not translated into Ifugao, the local language. Bangaan and Batad are part of the World Heritage site of Ifugao Rice Terraces. Other World Heritage sites, i.e., Nagacadan, Kiangan, and Hungduan, were not included in this study because they are outside the municipality of Banaue.

Fig. 3. Study location in the municipality of Banaue (b), Ifugao Province, Philippines (a). Along with the Barangays of Bangaan and Batad, two separate areas within the town of Banaue (blue) were surveyed (c).

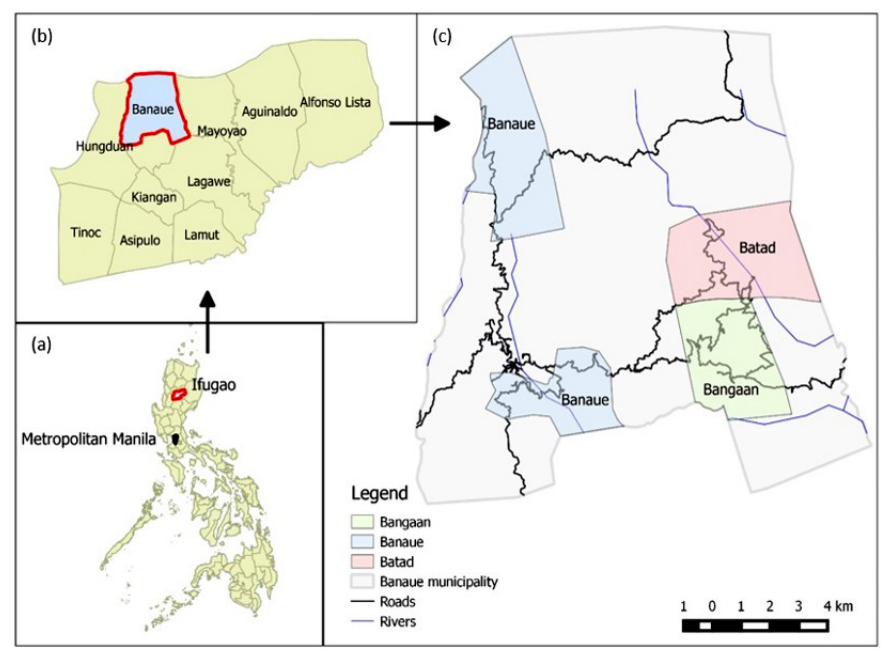

The surveys were followed by interviews with key informants, i.e., two employees of the Municipal Agriculture Office of Banaue; one Barangay capitan, who was a representative of the inhabitants of the Barangay; and two owners of local guesthouses (Table 2). This step was important to gain an in-depth understanding of each village, to make an inventory of rice varieties that may have different local names depending on the area, and to validate results from the surveys. The surveyed households were selected randomly, but all three locations were exposed to tourism, which is not the case for all villages in the Banaue municipality. Therefore, the evolution of the social-ecological systems of the three surveyed sites may not be representative of the systems located in more remote areas that are less exposed to tourism. The impact of tourism on the different sites is difficult to measure because tourist arrivals are not recorded outside the town of Banaue.

Table 2. Breakdown of interview participants and key informant interviews by study site.

\begin{tabular}{lccc}
\hline \hline Feature & \multicolumn{3}{c}{ Sites } \\
\cline { 2 - 4 } & Banaue & Bangaan & Batad \\
\hline UNESCO World & No & Yes & Yes \\
$\begin{array}{l}\text { Heritage Site } \\
\text { Total households }\end{array}$ & 788 & 169 & 235 \\
$\begin{array}{l}\text { Households } \\
\text { interviewed }\end{array}$ & 30 & 30 & 30 \\
$\begin{array}{l}\text { Key informant } \\
\text { interviews }\end{array}$ & 3 & 1 & 1 \\
\hline
\end{tabular}

\section{Data analyses}

The results were analyzed using descriptive statistics, including means and proportions. The total number of plant species grown for food (diversity of edible plants) and the total number of rice varieties (rice varieties) were analyzed by the species or variety richness, or total count, across the three study sites based on the households surveyed, and with the knowledge of the key informants. Richness was preferred to other biodiversity indices 
Table 3. Values for indicators of the state of the social-ecological system in Banaue. Changes in the value of each indicator as compared to the baseline values (see Table 1 for definitions and values) are shown as arrows ( $\uparrow=$ higher value; $\downarrow=$ lower value; - = no change).

\begin{tabular}{|c|c|c|c|c|c|}
\hline \multirow[t]{2}{*}{ Indicators } & \multicolumn{3}{|c|}{ Site } & \multirow[t]{2}{*}{ Total } & \multirow[t]{2}{*}{ Change } \\
\hline & Banaue & Bangaan & Batad & & \\
\hline Invasive alien species ${ }^{\dagger}$ & $0.60(0.08)$ & $0.63(0.07)$ & $0.71(0.08)$ & $0.64(0.5)$ & $\uparrow$ \\
\hline Rice diversity (number of varieties) ${ }^{\ddagger}$ & 6 & 10 & 8 & 17 & $\downarrow$ \\
\hline Number of uses of forest goods & 7 & 7 & 7 & 7 & - \\
\hline Months of food self-sufficiency ${ }^{\S}$ & $5.73(0.77)$ & $6.00(0.67)$ & $4.83(0.61)$ & $5.51(0.39)$ & - \\
\hline Number of plants for nutrition diversity ${ }^{\ddagger}$ & 24 & 34 & 27 & 50 & - \\
\hline Profitability $^{\dagger}$ & $0.56(0.09)$ & $0.50(0.09)$ & $0.37(0.09)$ & $0.48(0.05)$ & $\uparrow$ \\
\hline Traditional ecological practices $^{\dagger}$ & $0.37(0.09)$ & $0.10(0.06)$ & $0.10(0.06)$ & $0.19(0.04)$ & $\downarrow$ \\
\hline Primogeniture $^{\dagger}$ & $0.77(0.08)$ & $0.97(0.03)$ & $0.83(0.07)$ & $0.85(0.04)$ & - \\
\hline
\end{tabular}

${ }^{\dagger}$ proportion of households, ${ }^{\dagger}$ count, ${ }^{\S}$ mean.

Interviews were conducted at 30 households at each site, for a total of 90 . Standard errors are presented in parentheses.

because it allowed a comparison with baseline values, i.e., 48 species of edible plants and 28 rice varieties (Table 1). A test for independence of the presence of invasive alien species in each Barangay was conducted using $\chi^{2}$ analysis in $\mathrm{R}(\mathrm{R}$ Development Core Team 2012). Although the focus of the study was on the municipality of Banaue as a whole, these analyses were conducted to compare the social-ecological states of the Barangays and to see whether they have had different pathways over time.

\section{RESULTS}

The results are presented according to the adaptive management cycle introduced in the section on Indicators of Resilience and Adaptive Capacity. Following the DPSIR order, we first discuss the change of pressures and then the change of state, the change of impacts, and finally the change of response by comparing the current results with the findings of Barton $(1919,1922)$ and Conklin (1980, 1982).

\section{Change of pressures}

The proportion of households that have invasive alien species, i.e., golden apple snail, giant earthworm, and Asian swamp eel, as a main pest in their paddies was $64 \%$ (standard error [SE] $5 \%$; Table 3 ). Furthermore, according to the farmers, the giant earthworm has been the main pressure leading to the degradation of rice terraces over the last decade (33\% [SE 10\%] of households), followed by drought ( $27 \%$ [SE 9\%] of households), and landslides (24\% [SE 9\%] of households). The Asian swamp eel is the only pest species that was not mentioned in previous works in Banaue. Although it is perceived as the main pest species by only $6.6 \%$ of farmers in the Barangay of Banaue, some farmers fear that it may outcompete the earthworm as the most damaging pest.

Important pests that are considered as "native" because they were introduced before the first observations by Barton $(1919,1922)$ in the early 20th century are rodents, birds, and rice bugs (Leptocorisa spp.; Table 4). The perceived negative impacts of rodents on rice production are mainly related to Rattus tanezumi. Other indigenous species such as the common Philippine forest rat (Rattus everetti), the Luzon striped earth-rat (Chrotomys mindorensis), and the montane striped earth-rat (Chrotomys whiteheadi) may in fact be valuable to farmers because these vermivorous species are thought to feed on giant earthworms and on golden apple snails (Stuart et al. 2007). According to the farmers, other insect pests, e.g., planthoppers (Nilaparvata lugens), leaffolders (Nephotettix spp.), leafrollers (Cnaphalocrocis medinalis), and stem borers (Sesamia inferens, Scirpophaga spp., and Chilo spp.), or diseases, e.g., leaf blight and tungro virus disease, have only a minor impact on rice production in the area. There was no association between the proportion of any pest species and survey location $\left(\chi^{2}: P>0.05\right.$ for all pest species).

Table 4. Percentage of households that considered species as the main pest species in their field in each surveyed Barangay of the Banaue municipality.

\begin{tabular}{|c|c|c|c|c|}
\hline \multirow[t]{2}{*}{ Main pest species $^{\dagger}$} & \multicolumn{3}{|c|}{ Site } & \multirow[t]{2}{*}{$x^{2}$} \\
\hline & Banaue & Bangaan & Batad & \\
\hline \multicolumn{5}{|l|}{ Noninsect pests } \\
\hline Earthworms & 50.00 & 76.67 & 56.67 & 0.25 \\
\hline Rodents & 33.33 & 36.67 & 20.00 & 0.32 \\
\hline $\begin{array}{l}\text { Golden apple snails } \\
\text { (Pomacea canaliculata } \\
\text { [Lamarck]) }\end{array}$ & 13.33 & 20.00 & 16.67 & 0.09 \\
\hline Birds & 3.33 & 10.00 & 3.33 & 0.24 \\
\hline $\begin{array}{l}\text { Asian swamp eels } \\
\text { (Monopterus albus) }\end{array}$ & 6.67 & 0.00 & 0.00 & $3.52 *$ \\
\hline \multicolumn{5}{|l|}{ Insect pests } \\
\hline $\begin{array}{l}\text { Rice bugs (Leptocorisa } \\
\text { spp.) }\end{array}$ & 6.67 & 3.33 & 6.67 & 0.28 \\
\hline Grasshoppers & 0.00 & 3.33 & 0.00 & 0.55 \\
\hline $\begin{array}{l}\text { Leaffolders (Nephotettix } \\
\text { spp.) }\end{array}$ & 0.00 & 3.33 & 0.00 & 0.55 \\
\hline $\begin{array}{l}\text { Stem borers (Sesamia } \\
\text { inferens, Scirpophaga spp., } \\
\text { and Chilo spp.) }\end{array}$ & 3.33 & 0.00 & 0.00 & 1.65 \\
\hline
\end{tabular}

${ }^{\dagger}$ Multiple responses were possible.

* $P<0.1$.

Interviews were conducted at 30 households at each site, for a total of 90 .

\section{Change of state}

With the help of a rice farmer, Conklin (1982) identified 28 different nonglutinous varieties of rice during a field survey in 8 different districts of the town of Banaue. In the present study, only 17 varieties were inventoried using their Ifugao rice names across the 3 study sites with the help of interviewed farmers and an employee of the Municipal Agriculture Office of Banaue. This 
lower number, which represents a decline of $39 \%$, may partly be explained by the low number of sample sites in the present study, the change of knowledge about rice varieties, and preference for higher yielding varieties. Some farmers also found the traditional varieties to be more vulnerable to rodents than introduced varieties.

Of the 17 rice varieties we found, 9 were described as autochthonous in the Ifugao province, 6 were from different provinces in the Philippines, and 2 were of unknown origin. ${ }^{[1]}$ Furthermore, 11 varieties were used as a first or single crop approximately from December to July, during the dry season; and 6 (most of which were grown in Bangaan) were used as the second crop approximately from August to November, during the rainy season. Three varieties were grown at all 3 Barangays (Fig. 4), whereas most of the other varieties were specific to a single study site. Conklin (1982) did not mention the origin or the distribution of the varieties inventoried but identified 17 varieties for the first crop and 11 varieties for the second crop of the year.

Fig. 4. Varieties of nonglutinous rice cultivated among the surveyed households ( $n=30$ in each Barangay) at the three study sites. Tinawon and pinidua, meaning "yearly" and "second crop," respectively, are two categories that may include several autochthonous varieties that are not differentiated by local farmers.

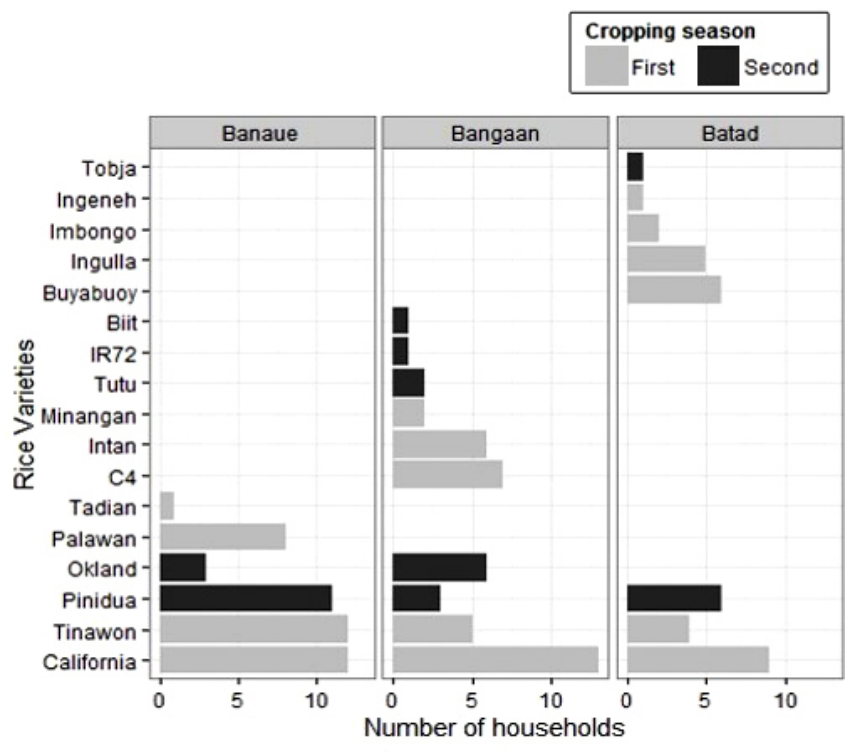

There appears to have been little change in the total number of plant species grown for food in the surrounding agroecosystems, which besides rice paddies include private gardens, woodlots, and swidden fields. Conklin (1980) observed 48 different cultivated plant species, whereas the present study identified 50 species used for consumption, most of which were vegetables and fruit trees growing in family gardens and private woodlots (Appendix 1). Plant species inventoried in this study that were not listed in Conklin's work include Garcinia benthami (Bulon in Ifugao), Sechium edule (chayote), Shorea astylosa (Bultic in Ifugao), Origanum vulgare (oregano), Medinilla speciosa (showy Asian grapes), Sandoricum koetjape (santol), Psidium guajava (guava),
Antidesma leptocladum (Galiwgiwon in Ifugao), Dacrycarpus imbricatus (Gutmu in Ifugao), Rubus rosifolius (roseleaf bramble), Evodia meliaefolia (Galikon in Ifugao), Moringa oleifera (moringa), Solanum nigrum (black nightshade), and Premna odorata (fragrant premna). Several of these plants species were introduced to the area in the past decades, but the farmers did not notice any negative impacts from their introduction, as opposed to the introduction of aquatic animal species, e.g., golden apple snail.

\section{Change of impacts}

The private forests of Banaue have maintained their multifunctionality. The inhabitants of Banaue still use forest goods, which fall into seven categories. Forest goods were used by households mostly for food, firewood, construction, and organic fertilizer. According to the respondents, the use of plants for medicinal purposes, handicrafts, and natural pesticides is not as common as before. Some medicinal plants and plants that were used to prevent pest damage were only collected during specific rituals, and native priests were the only ones allowed to pick and process the plants. Because rituals are becoming uncommon, some plants are being used to a lesser extent. The use of wood for handicrafts has lessened because the wood supply has been restricted by a national logging ban aimed at preserving the remaining natural forests in the Philippines (Acabado 2012) and because of a recent decrease in the numbers of tourists (NSCB 2014). On average, households use forest goods for 3 (SE 0.5) different purposes, mainly for food, firewood, and construction.

With food self-sufficiency averaging 5.5 (SE 0.4) months, rice production in the present study has not significantly changed since the first accounts of the social-ecological system by ethnologists during the last century. Barton (1919) and Conklin (1980) noted that although some farmers could produce rice for a whole year and others for only 1 or 2 months per year, the yearly rice harvest for most households was sufficient for approximately 6 months, which represents the baseline value of self-sufficiency for this study (Table 1). Sweet potatoes were traditionally an important part of the diet (Conklin 1980, Brosius 1988), but households now buy imported rice to complement their rice harvest.

The profitability of the system has not considerably increased despite a higher number of households earning some money from the development of the tourism industry and the introduction of more productive rice varieties coming from other regions of the Philippines in the lower terraces of the villages. Trade has always been present in the municipality, with a barter system based on rice as the main exchange commodity (Barton 1919), but a monetary income allows families to afford college education for their children and family health care services. About half of the surveyed households (48\% [SE 5\%]) gain some income from either agricultural activities, e.g., selling fruits and vegetables, or tourism, e.g., selling handicrafts. Only four households across the three sites were able to sell some of their harvested rice. With the exception of two respondents, who owned a guest house and received nearly $100 \%$ of their cash income from tourism, all households received an irregular and low amount of money amounting to less than $10 \%$ of their total income from the socialecological system. Most families rely on off-farm employment and remittance from family members, generally from outside the Ifugao province. 


\section{Change of responses}

The proportion of households that still perform rituals has greatly declined over the last decades. Only about 20\% (SE 4\%) of households across the 3 surveyed areas now hold rituals related to agriculture, and among the households that still do, an average of 4 rituals are performed per year. This number is significantly fewer than that previously reported by Conklin (1980), who counted 17 rituals for agricultural purposes performed by 9 out of 11 households in 1962-1963 in a Barangay of Banaue with about 50 inhabitants. The farmers claim that this shift is mostly for socioeconomic reasons, i.e., the conversion to Christianity and the high costs for farmers to purchase animals for sacrifices required for the rituals. For instance, Conklin (1980) stated that a total of 467 chickens, 76 pigs, and 4 carabaos were sacrificed during the 17 rituals over 1 year.

A relatively high proportion of households (85\% [SE 4\%]) have conserved the tradition of primogeniture for land inheritance. Conklin (1980) found that a large majority of families passed rice paddy ownership to the firstborn child. Because the paddies and woodlots cannot be divided among all the children according to the ancestral tradition, the children who do not inherit land must either become tenants or seek education and work in the nearest urban centers. The farmers considered this tradition as important to ensure that rice plots are not divided among several heirs and reduced in size.

\section{DISCUSSION}

Several indicators of the social-ecological system of Banaue have remained constant through time. This is the case with the multifunctionality of forests, nutrition diversity, food selfsufficiency, and the primogeniture inheritance system, which shows that ecosystem services and related benefits have in a large part been conserved despite changes in the social and ecological subsystems. The perceived impact of invasive alien species has been a major concern in the area for a number of years (Joshi et al. 1999, 2000, 2001), and there is a lack of knowledge of management measures to cope with this new pressure. However, despite the negative perception of the golden apple snail, the presence of invasive snails could provide some benefits by decreasing time spent weeding rice fields: The farmers in Banaue spend a great amount of time removing weeds after the seedbed stage (Conklin 1980). Martin et al. (1998) found that in the presence of other aquatic plants, the golden apple snail would not feed on rice but rather on other plants and weeds, and thus could help to reduce the weeding effort of the farmers. The practice of traditional rituals has decreased, and many traditional rice varieties have been abandoned by some farmers in favor of varieties that allow two crops per year. The income from the socialecological system gained by the farmers remains low, and a majority of farmers needs to find off-farm employment.

\section{Uncertainties in the study}

Because of the remoteness of the case study location and the lack of long-term datasets, indicators were chosen for their applicability and the possibility of deriving them from questionnaire results. For instance, food self-sufficiency was preferred to other conventional indicators of rice provisioning, such as the yield (measured in $\mathrm{kg} \mathrm{ha}^{-1} \mathrm{yr}^{-1}$ ), because most farmers in Banaue are not aware of the total area of their fields. Rice terraces typically circumvent the steep mountain slopes, and as a result, their area and contour are highly variable in shape and size. Furthermore, the rice bundles, which are often used as a quantification unit for rice yields, can be of different sizes in each community, and even within a single village or household, which makes spatial and temporal comparisons of yields difficult.

The surveys are based on the perception by the farmers of their social-ecological system. The information collected gives an insight into how the farmers view the long-term development of their communities and the surrounding ecosystems. However, the survey results can be biased depending on the knowledge and motivations of the farmers.

\section{Cultural ecosystem services and response to pressure}

Cultural services from rice ecosystems, such as traditional ecological knowledge and spiritual or religious experience and their resulting benefits, are gradually being lost, possibly after the commercialization of the traditional culture for tourism purposes (Bulilan 2007), Christianization (Nozawa et al. 2008), and the high costs of holding rituals. Although the potential for supply of these cultural ecosystem services is still present (e.g., some heirloom varieties are still grown), the demand for the services is decreasing (e.g., younger generations are losing interest in agricultural activities; Dizon et al. 2012). As education and employment opportunities increase in the cities, the younger generation is less attracted by the perspective of pursuing rice cultivation, and traditional ecological practices, such as the breeding of heirloom rice varieties by village elders, could be lost. Thus, as the population favors off-farm employment, it is possible that farmer knowledge concerning the identification of rice varieties and plant species will decline. This may partly explain the relatively low number of rice varieties we found in this area compared with the number found by Conklin (1982). Migration is already a common phenomenon in Ifugao that has impacts on farmers' decisions and land use (Mckay 2003), and an acceleration of migration could result in widespread abandonment of the terraces. However, the cultural heritage remains strong, and the tradition of primogeniture ensures for the moment the continuity of rice cultivation.

The change in the practice of rituals may affect land-use practices, e.g., the synchronicity of the cropping season, which relates to the timing of rice transplanting and which was tightly accompanied by rituals in the past. Such changes may lead to greater pest problems because of poor synchronization of planting; e.g., damage by $R$. tanezumi and planthoppertransmitted rice viruses increase with poor synchrony of crops (Miller et al. 2008). Damage caused by rice bugs is also believed by farmers to be much higher when rice crops are harvested later than traditionally required by harvesting rituals.

Concerning the pressure of pest species, further research could help to clarify the impact of the the giant earthworm and the golden apple snail on rice production and the populations of other aquatic species. The information used to assess the current state of the system comes from farmers who may not be properly trained in the identification of gastropods or annelid worms. For instance, doubts have been expressed concerning the ability of farmers to correctly differentiate between $P$. canaliculata and native snail species (Joshi et al. 2000, 2001), and the earthworm pest problem may be overestimated by the local population because the worm is rarely seen by researchers (Settele and Plachter 1998). 


\section{Alternative states and future trajectories}

Studies of alternative states and regime shifts are gaining increased attention in research on system resilience (Folke et al. 2004, Kinzig et al. 2006). However, few authors have explored alternative states and their consequences for traditional rice terracing (Plachter et al. 1998, Lansing et al. 2014, Qiu et al. 2014). Scenarios for the development of the system can be divided into two categories: (1) development with a varying degree of resilience without a regime shift and (2) development without resilience leading to a regime shift.

The first possibility consists of the system conserving its structures, processes, and functions, i.e. conserving the cultivation of rice as the main crop because rice paddies are the central element of the social-ecological system in Banaue, with a variable range of vulnerability to disturbances and adaptability (Fig. 5). A system that could overcome a disturbance and conserve its function and values for indicators of state, impact, and response would show its robustness to change (trajectory B in Fig. 5). If the system is able to take advantage of environmental and social changes, resulting in higher values for these indicators, this would demonstrate its capacity to adapt to pressures in the system and maintain its resilience (trajectory A). Such a trajectory could occur if, for instance, the implementation of ecotourism would help farmers to capture a high rent from tourism while preserving natural and cultural heritage (Calderon et al. 2008). Similarly, a system of extensive and intensive agricultural techniques (Acabado 2012) that would improve profitability and food selfsufficiency while conserving traditional rice varieties would demonstrate its adaptive capacity in response to the pressure to integrate into the market economy. Currently, pest damage and large families offset the gains from introduced rice varieties, and few households are able to sell the products of their rice fields.

Fig. 5. Potential system trajectories that may also apply to the landscape of Banaue. In trajectory A, the system recovers from the perturbation and is able to take advantage of new opportunities, therefore demonstrating adaptability. Trajectory $\mathrm{B}$ shows a robust system that conserves the same level of ecosystem services and benefits after recovery from the perturbation. Trajectory $\mathrm{C}$ shows vulnerability of the system to perturbation and the incapacity of the system to fully recover from the disturbance, but without necessarily experiencing a shift of the fundamental social-ecological system structures, processes, and functions.

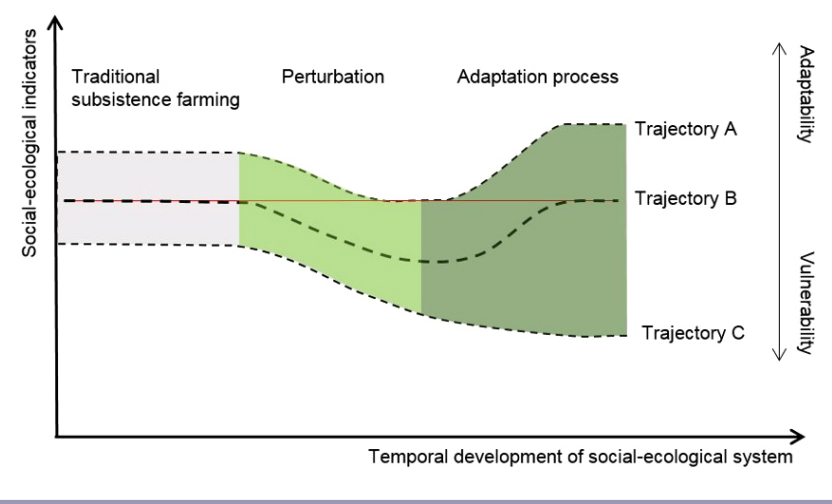

The social-ecological system in Banaue can be assumed to be in a late conservation phase, and possibly beginning a readjustment phase according to the declining values of some indicators (traditional ecological practices and rice diversity) and higher pressures (invasive alien species), when compared with the reference system (trajectory C). Efforts for the conservation of the rice terraces are intensifying at the local, national, and international levels, and the high vulnerability of the system has been demonstrated by its inclusion in the List of World Heritage [sites] Danger for 11 years (UNESCO 2012).

A regime shift could be triggered if perturbations would provoke a change of characteristic structures and processes, and thus transform the system. A possible alternative state of the system would be the shift from rice cultivation to vegetables or other cash crops, for instance Phaseolus vulgaris, which has been planted in other areas of Ifugao (Gomez and Pacardo 2005), but seems to be nonprofitable in the long term (Engelhard et al. 1991). Because the social-ecological system in Banaue revolves around rice production, the abandonment of rice cultivation would result in a regime shift with the alteration of several variables, especially profitability, the diversity of plant species cultivated, and more generally, cultural ecosystem services such as tourism and traditional ecological practices.

A shift toward intensification of agriculture centering on a cash crop other than rice would entail the loss of cultural and aesthetic values, and a reduced abundance of adapted species (Benayas et al. 2007). A natural secondary succession characterized by reforestation of the slopes is also possible because of surrounding forests. The reforestation trend has been ongoing over the last decades because of the abandonment of swidden cultivation (Herzmann et al. 1998); for instance, at Mayoyao, also a municipality within the Ifugao Rice Terraces, abandoned rice terraces have been replaced by forest (Bantayan et al. 2012).

\section{CONCLUSIONS}

This study used eight indicators integrating socioeconomic and ecological components of the Banaue rice terraces to assess the state of the social-ecological system with a focus on perceptions by the local community. From the indicators categorized by DPSIR components, resilience and adaptability were inferred. This method required a simplification of the system dynamics, but provided a first insight into the change of the social-ecological system in Banaue by assessing the changes in the current value of the indicators compared with previous findings. Linkages between ecosystem services and the resulting human well-being were discussed, highlighting the loss of cultural services and traditional ecological practices. Potential trajectories of the system in the long term were also examined.

To better assess the long-term development of the region, more system components should be monitored, measured, or modeled on a longer time scale. For instance, an exhaustive biodiversity survey could be conducted in Banaue because uncertainties remain concerning the impacts of exotic species on rice yields and on native species. Similarly, the impact of tourism should be further investigated in other towns of the Ifugao terraces to understand how the local communities can take advantage of this new reality without compromising their cultural heritage. Data should be made available at different time intervals to give a better idea of potential system trajectories, resilience, and adaptive 
capacity. More indicators, e.g., of the drivers of change in the system, could be added to the DPSIR-ecosystem services framework.

The traditional knowledge and the ecosystems of the Banaue rice terraces' social-ecological system are a result of a long-term coevolution. The terraces are valued both nationally and internationally, showing the importance of this landmark for the Philippines and the rich legacy of the codevelopment between human communities and native ecosystems.

The system has not yet shifted to an alternative state and seems to keep, at least for the moment, its main characteristic features (state, impact, and response indicators) despite several changes. However, it is now subject to several pressures that simultaneously threaten the conservation of its landscape and its social subsystems. Adequate responses to pressures will be needed if traditional and sustainable production of rice on terraces as a livelihood for local people is to be conserved together with the multiple ecosystem services and other benefits that the terraces provide.

[1] The count of rice varieties does not include glutinous rice varieties ("sticky rice" used in Ifugao notably for the confection of desserts and rice wine) because glutinous rice is not used as a staple food.

Responses to this article can be read online at: http://www.ecologyandsociety.org/issues/responses. $\mathrm{php} / 8348$

\begin{abstract}
Acknowledgments:
This research was completed as part of the LEGATO project (Landuse intensity and Ecological Engineering-Assessment Tools for Risks and Opportunities in Irrigated Rice Based Production Systems; German Ministry of Research and Education BMBF Funding No. 01LL0917F; Settele et al. 2013, 2015). We would like to acknowledge the field assistants and interpreters, especially Laeticia Palayon and Virginia Hangdaan from Bangaan, Hilario and Harry Biwit from Tam-an, Alfredo Bunnol and Marcos Mulao from Poitan, Aida Paganahe and Jesus Victor Bustamante from Banaue, and anonymous participants for giving their valuable time and expertise to this study. This work was carried out with the aid of a grant from the Advisory Service on Agricultural Research for Development (Beratungsgruppe Entwicklungsorientierte Agrarforschung, $B E A F)$ program of the Deutsche Gesellschaft für Internationale Zusammenarbeit (GIZ). We are grateful for the constructive feedback from the anonymous reviewers, which helped to considerably improve the manuscript.
\end{abstract}

\section{LITERATURE CITED}

Acabado, S. 2009. A Bayesian approach to dating agricultural terraces: a case from the Philippines. Antiquity 83(321):801-814. http://dx.doi.org/10.1017/s0003598x00099002

Acabado, S. 2012. The Ifugao agricultural landscapes: agrocultural complexes and the intensification debate. Journal of
Southeast Asian Studies 43(03):500-522. http://dx.doi.org/10.1017/ s0022463412000367

Agus F., I. Irawan, H. Suganda, W. Wahyunto, A. Setiyanto, and M. Kundarto. 2006. Environmental multifunctionality of Indonesian agriculture. Paddy and Water Environment 4 (4):181-188. http://dx.doi.org/10.1007/s10333-006-0047-5

Araral, E. 2013. What makes socio-ecological systems robust? An institutional analysis of the 2,000 year-old Ifugao society. Human Ecology 41(6):859-870.

Bantayan, N. C., M. M. Calderon, J. T. Dizon, A. J. U. Sajise, and M. G. Salvador. 2012. Estimating the extent and damage of the UNESCO World heritage sites of the Ifugao. Journal of Environmental Science and Management 15(1):1-5.

Barrion, A. T., and J. A. Litsinger. 1997. Dichogaster nr. curgensis Michaelsen (Annelida: Octochaetidae): an earthworm pest of terraced rice in the Philippine Cordilleras. Crop Protection 16 (1):89-93.

Barton, R. F. 1919. Ifugao law. University of California Press, Berkeley, California, USA.

Barton, R. F. 1922. Ifugao economics. University of California Press, Berkeley, California, USA.

Bélair, C., K. Ichikawa, B. Wong and K. Mulongoy. 2010. Sustainable use of biological diversity in socio-ecological production landscapes. Background to the 'Satoyama Initiative for the benefit of biodiversity and human well-being.' Technical Series no. 52. Secretariat of the Convention on Biological Diversity, Montreal, Quebec, Canada.

Benayas, J. R., A. Martins, J. M. Nicolau, and J. J. Schulz. 2007. Abandonment of agricultural land: an overview of drivers and consequences. CAB Reviews: Perspectives in Agriculture, Veterinary Science, Nutrition and Natural Resources 2:1-14. http:// dx.doi.org/10.1079/pavsnnr20072057

Bergamini, N., R. Blasiak, P. Eyzaguirre, K. Ichikawa, D. Mijatovic, F. Nakao, and S. M. Subramanian. 2013. Indicators of resilience in socioecological production landscapes (SEPLs). UNUIAS Policy Report. United Nations University Institute of Advanced Studies, Yokohama, Japan.

Beyer, O. 1955. The origin and history of the Philippine rice terraces. National Research Council of the Philippines, Quezon City, Philippines.

Brosius, J. P. 1988. Significance and social being in Ifugao agricultural production. Ethnology 27(1):97-110. http://dx.doi. org/10.2307/3773563

Bulilan, C. M. R. 2007. Experiencing cultural heritage and indigenous tourism in Banaue. Philippine Quarterly of Culture and Society 35(1):100-128.

Burkhard, B., and F. Müller. 2008. Drivers-pressure-state-impactresponse. Pages 967-970 in S. E. Jørgensen and B. D. Fath, editors. Ecological indicators. Volume 2 of Encyclopedia of ecology. Elsevier, Oxford, UK. http://dx.doi.org/10.1016/

b978-008045405-4.00129-4

Burkhard, B., A. Müller, F. Müller, V. Grescho, Q. Anh, G. Arida, J. V. Bustamante, H. van Chien, K. L. Heong, M. Escalada, L. 
Marquez, D. T. Truong, S. Villareal, and J. Settele. 2015. Land cover-based ecosystem service assessment of irrigated rice cropping systems in southeast Asia-an explorative study. Ecosystem Services 14:76-87. http://dx.doi.org/10.1016/j. ecoser.2015.05.005

Burkhard, B., S. Opitz, H. Lenhart, K. Ahrendt, S. Garthe, B. Mendel, and W. Windhorst. 2011. Ecosystem based modeling and indication of ecological integrity in the German North Sea-case study offshore wind parks. Ecological Indicators 11(1):168-174. http://dx.doi.org/10.1016/j.ecolind.2009.07.004

Cabell, J. F., and M. Oelofse. 2012. An indicator framework for assessing agroecosystem resilience. Ecology and Society 17(1):18. http://dx.doi.org/10.5751/ES-04666-170118

Calderon, M. M., J. T. Dizon, A. J. U. Sajise, R. T. Andrada II, N. C. Bantayan, and M. G. Salvador. 2008. Towards the development of a sustainable financing mechanism for the conservation of the Ifugao Rice Terraces in the Philippines. EEPSEA Research Report No. 2008-RR10. Economy and Environment Program for Southeast Asia, Singapore. [online] URL: http://web.idrc.ca/uploads/user-S/12476447771Marge_2008_RR10. pdf

Christie, M., I. Fazey, R. Cooper, T. Hyde, and J. O. Kenter. 2012. An evaluation of monetary and non-monetary techniques for assessing the importance of biodiversity and ecosystem services to people in countries with developing economies. Ecological Economics 83:67-78. http://dx.doi.org/10.1016/j.ecolecon.2012.08.012

Conklin, H. C 1980. Ethnographic atlas of Ifugao: a study of environment, culture, and society in northern Luzon. Yale University Press, New Haven, Connecticut, USA.

Conklin, H. C. 1982. Ifugao rice varieties. IRRI Seminar Papers 1(6), August 10, 1982. International Rice Research Institute, Los Banos, Philippines.

Dizon, J. T., M. M. Calderon, A. J. U. Sajise, R. T. Andrada II, and M. G. Salvador. 2012. Youths' perceptions of and attitudes towards the Ifugao rice terraces. Journal of Environmental Science and Management 15(1):52-58.

Engelhard, B., J. Keck, and J. Settele. 1991. Bean growing in Ifugao province, Philippines: a preliminary survey of socioeconomic conditions and plant protection problems in Phaseolus vulgaris L. Philippine Agriculturist 74:471-477.

Fletcher, C., and D. W. Hilbert. 2007. Resilience in landscape exploitation systems. Ecological Modelling 201(3):440-452. http:// dx.doi.org/10.1016/j.ecolmodel.2006.10.011

Folke, C. 2006. Resilience: the emergence of a perspective for social-ecological systems analyses. Global Environmental Change 16(3):253-267. http://dx.doi.org/10.1016/j.gloenvcha.2006.04.002

Folke, C., S. R. Carpenter, B. Walker, M. Scheffer, T. Chapin, and J. Rockstrüm. 2010. Resilience thinking: integrating resilience, adaptability and transformability. Ecology and Society 15(4):20. [online] URL: http://www.ecologyandsociety.org/vol15/iss4/ $\underline{\operatorname{art} 20 /}$

Folke, C., S. Carpenter, B. Walker, M. Scheffer, T. Elmqvist, L. Gunderson, and C. S. Holling. 2004. Regime shifts, resilience, and biodiversity in ecosystem management. Annual Review of
Ecology, Evolution, and Systematics 35(1):557-581. http://dx.doi. org/10.1146/annurev.ecolsys.35.021103.105711

Garaway, C. J., C. Photitay, K. Roger, L. Khamsivilay, and M. Halwart. 2013. Biodiversity and nutrition in rice-based ecosystems; the case of Lao PDR. Human Ecology 41(4):547-562. http://dx.doi.org/10.1007/s10745-013-9602-z

Gomez, R., and E. Pacardo. 2005. Survey of the damage in the Ifugao rice terraces and its environmental dynamics. Philippine Agricultural Scientist 88(1):133-137.

Gu, H., Y. Jiao, and L. Liang. 2012. Strengthening the socioecological resilience of forest-dependent communities: the case of the Hani Rice Terraces in Yunnan, China. Forest Policy and Economics 22:53-59. http://dx.doi.org/10.1016/j.forpol.2012.04.004

Guimbatan, R., and T. Baguilat, Jr. 2006. Misunderstanding the notion of conservation in the Philippine rice terraces - cultural landscapes. International Social Science Journal 58(187):59-67. http://dx.doi.org/10.1111/j.1468-2451.2006.00606.x

Haines-Young, R. H., and M. P. Potschin. 2010. The links between biodiversity, ecosystem services and human well-being. Pages 110-139 in D. G. Raffaelli and C. L. J. Frid, editors. Ecosystem ecology: a new synthesis. BES Ecological Reviews Series. Cambridge University Press, Cambridge, UK. http://dx.doi. org/10.1017/cbo9780511750458.007

Hayama, A. 2003. Local forest management in the rice terrace area of Banaue, the Philippines. Pages 275-286 in M. Inoue and H. Isozaki, editors. People and forest-policy and local reality in Southeast Asia, the Russian Far East, and Japan. Institute for Global Environmental Strategies 3. Springer, Dordrecht, Netherlands. http://dx.doi.org/10.1007/978-94-017-2554-5 18

Herzmann, S., A. Jost, T. Korbun, C. Willerding, J. Settele, and H. Plachter. 1998. Ifugao rice terraces-landuse changes in a traditional agroecosystem from 1963 to 1997 . Pages 77-89 in J. Settele, H. Plachter, J. Sauerborn, and D. Vetterlein, editors. Rice terraces of Ifugao (Northern-Luzon Philippines), conflicts of landuse and environmental conservation. UFZ-Bericht 5/1998. Helmholtz Centre for Environmental Research, Leipzip, Germany.

Holling, C. S. 1973. Resilience and stability of ecological systems. Annual Review of Ecology, Evolution, and Systematics 4:1-23. http://dx.doi.org/10.1146/annurev.es.04.110173.000245

Joshi, R. C., M. S. Delacruz, E. C. Martin, J. C. Cabigat, R. G. Bahatan, A. D. Bahatan, E. H. Abayao, J. Choy-Awon, N. P. Chilagan, and A. B. Cayong. 2001. Current status of the golden apple snail in the Ifugao Rice Terraces, Philippines. Journal of Sustainable Agriculture 18(2-3):71-90. http://dx.doi.org/10.1300/ j064v18n02 07

Joshi, R., O. R. O. Matchoc, R. G. Bahatan, and F. A. D. Peña. 2000. Farmers' knowledge, attitudes and practices of rice crop and pest management at Ifugao Rice Terraces, Philippines. International Journal of Pest Management 46(1):43-48. http://dx. doi.org/10.1080/096708700227561

Joshi, R. C., O. R. O. Matchoc, J. C. Cabigat, and S. W. James. 1999. Survey of earthworms in the Ifugao Rice Terraces. Journal of Environmental Science and Management 2(2):1-12. 
Kinzig, A. P., P. Ryan, M. Etienne, H. Allison, T. Elmqvist, and B. H. Walker. 2006. Resilience and regime shifts: assessing cascading effects. Ecology and Society 11(1):20. [online] URL: http://www.ecologyandsociety.org/vol11/iss1/art20

Klotzbücher, T., A. Marxen, D. Vetterlein, J. Schneiker, M. Türke, N. van Sinh, N. H. Manh, H. van Chien, L. Marquez, S. Villareal, J. V. Bustamanteh, and R. Jahn. 2015. Plant-available silicon in paddy soils as a key factor for sustainable rice production in Southeast Asia. Basic and Applied Ecology 16:665-673. http://dx. doi.org/10.1016/j.baae.2014.08.002

Koohafkan, P., and M. J. D. Cruz. 2011. Conservation and adaptive management of globally important agricultural heritage systems (GIAHS). Journal of Resources and Ecology 2(1):22-28.

Lansing, J. S. 1987. Balinese "water temples" and the management of irrigation. American Anthropologist 89(2):326-341. http://dx. doi.org/10.1525/aa.1987.89.2.02a00030

Lansing, J. S., and J. N. Kremer. 1993. Emergent properties of Balinese water temple networks: coadaptation on a rugged fitness landscape. American Anthropologist 95(1):97-114. http://dx.doi. org/10.1525/aa.1993.95.1.02a00050

Lansing J. S., S. A. Cheong, L. Y. Chew, M. P. Cox, M.-H. R. Ho, and W. A. Arthawiguna. 2014. Regime shifts in Balinese Subaks. Current Anthropology 55(2):232-239.

Lorenzen, R. P., and S. Lorenzen. 2011. Changing realitiesperspectives on Balinese rice cultivation. Human Ecology 39 (1):29-42. http://dx.doi.org/10.1007/s10745-010-9345-Z

Lu, J., and X. Li. 2006. Review of rice-fish-farming systems in China - one of the Globally Important Ingenious Agricultural Heritage Systems (GIAHS). Aquaculture 260(1-4):106-113. http://dx.doi.org/10.1016/j.aquaculture.2006.05.059

Maher, R. F. 1974. Archaeological investigations in Central Ifugao. Asian Perspectives 16(1):39-70.

Margraf, J., and M. Voggesberger. 1984. Biological aspects of the traditional agro-ecosystems of Ifugao, Philippines. 5th IFOAM Conference on the Importance of Biological Agriculture in a World of Diminishing Resources, Witzenhausen, Germany.

Martin, K., H. Grülz, and S. Holzhauer. 1998. Field studies on the golden snail in the Ifugao rice terrces. Pages 55-61 in J. Settele, H. Plachter, J. Sauerborn, and D. Vetterlein, editors. Rice terraces of Ifugao (Northern-Luzon Philippines), conflicts of landuse and environmental conservation. UFZ-Bericht 5/1998. Helmholtz Centre for Environmental Research, Leipzip, Germany.

McKay, D. 2003. Cultivating new local futures: remittance economies and land-use patterns in Ifugao, Philippines. Journal of Southeast Asian Studies 34(2):285-306. http://dx.doi. org/10.1017/s0022463403000262

Miller, R.W., A. M. Stuart, R. C. Joshi, P. B. Banks, and G. R. Singleton. 2008. Biology and management of rodent communities in complex agroecosystems-rice terraces. Pages 25-36 in G. R. Singleton, R. C. Joshi, and L. S. Sebastian, editors. Philippine rats: ecology \& management. Philippine Rice Research Institute. Science City of Muñoz, Nueva Ecija, Philippines.
Müller, F., and B. Burkhard 2012. The indicator side of ecosystem services. Ecosystem Services 1(1):26-30. http://dx.doi.org/10.1016/ j.ecoser.2012.06.001

National Statistical Coordination Board (NSCB). 2014. Visitor arrivals by country of origin province of ifugao, 2007-2012. Special tables on tourism statistics. NSCB, Quezon City, Philippines. [online] URL: http://www.nscb.gov.ph/rucar/stat trsm ifu.htm

Nozawa, C., M. Malingan, A. Plantilla, and J.-E. Ong. 2008. Evolving culture, evolving landscapes: the Philippine rice terraces. Pages 71-93 in T. Amend, J. Brown, A. Kothari, A. Phillips, and S. Stolton, editors. Protected landscapes and agrobiodiversity values. Volume 1. Protected landscapes and seascapes. International Union for Conservation of Nature (IUCN) and Deutsche Gesellschaft für Technische Zusammenarbeit (GTZ), Heidelberg, Germany.

Olofson, H. 1983. Indigenous agroforestry systems. Philippine Quarterly of Culture and Society 11:149-174.

Peljor N., and N. Minot 2010. Food security and food selfsufficiency in Bhutan. Summary report of the Agricultural and Food Policy Research and Capacity Strengthening Project. International Food Policy Research Institute, Washington, D.C., USA.

Pimm, S. L. 1984. The complexity and stability of ecosystems. Nature 307(5949):321-326. http://dx.doi.org/10.1038/307321a0

Plachter H, J. Sauerborn, D. Vetterlein, and J. Settele. 1998. Scenarios for the future development of the Ifugao Rice Terraces (N-Luzon, Philippines). Pages 91-102 in J. Settele, H. Plachter, J. Sauerborn, and D. Vetterlein, editors. Rice terraces of Ifugao (Northern-Luzon Philippines), conflicts of landuse and environmental conservation. UFZ-Bericht 5/1998. Helmholtz Centre for Environmental Research, Leipzip, Germany.

Qiu Z., B. Chen, and K. Takemoto. 2014. Conservation of terraced paddy fields engaged with multiple stakeholders: the case of the Noto GIAHS site in Japan. Paddy and Water Environment 12(2):275-283. http://dx.doi.org/10.1007/s10333-013-0387-x

R Development Core Team. 2012. R: a language and environment for statistical computing. R Project for Statistical Computing, Vienna, Austria. [online] URL: http://www.R-project.org/

Roxas, J. P. 1996. Isozyme analysis, morpho-agronomic traits and grain quality of traditional rice varieties (Oryza sativa L.) of Ifugao. Thesis. Gregorio Araneta University Foundation, Malabon City, Metro Manila, Philippines.

Save the Ifugao Terraces Movement (SITMo). 2008. IMPACT: the effects of tourism on culture and the environment in Asia and the Pacific: sustainable tourism and the preservation of the World Heritage Site of the Ifugao Rice Terraces, Philippines. UNESCO, Bangkok, Thailand.

Scheffer, M., S. R. Carpenter, T. M. Lenton, J. Bascompte, W. Brock, V. Dakos, J. van de Koppel, I. A. van de Leemput, S. A. Levin, E. H. van Nes, M. Pascual, and J. Vandermeer. 2012. Anticipating critical transitions. Science 338(6105):344-348. http://dx.doi.org/10.1126/science.1225244 
Serrano, R. C., and E. A. Cadaweng. 2005. The Ifugao Muyong: sustaining water, culture and life. Pages 103-112 in P. B. Durst, C. Brown, H. D. Tacio, and M. Ishikawa, editors. Search of excellence: exemplary forest management in Asia and the Pacific. Regional Community Forestry Training Center for Asia and the Pacific, Food and Agriculture Organization of the United Nations, Rome, Italy.

Settele, J., I. Kühn, S. Klotz, G. Arida, E. Bergmeier, B. Burkhard, J. V. Bustamante, D. T. Truong, M. Escalada, C. Gürg, V. Grescho, H. van Chien, K. L. Heong, N. Hirneisen, S. Hotes, R. Jahn, T. Klotzbücher, G. Marion, L. Marquez, A. Marxen, R. Moritz, F. Müller, N. V. Sinh, J. Ott, L. Penev, B. Rodriguez-Labajos, M. Schädler, S. Scheu, R. Seppelt, P. Stoev, T. Tscharntke, V. Tekken, K. Thonicke, D. Vetterlei, S. Vidal, S. Villareal, W. W. Weisser, C. Westphal, M. Wiemers, and J. H. Spangenberg. 2013. Kulturlandschaftsforschung in Südostasien-das LEGATOProjekt. Berichte. Geographie und Landeskunde 87(3):315-323.

Settele, J., and H. Plachter. 1998. The rice terrace system and the earthworm problem. Pages 63-64 in J. Settele, H. Plachter, J. Sauerborn, and D. Vetterlein, editors. Rice terraces of Ifugao (Northern-Luzon Philippines), conflicts of landuse and environmental conservation. UFZ-Bericht 5/1998. Helmholtz Centre for Environmental Research, Leipzip, Germany.

Settele, J., J. H. Spangenberg, K. L. Heong, B. Burkhard, J. V. Bustamante, J. Cabbigat, H. V. Chien, M. Escalada, V. Grescho, L. H. Hai, A. Harpke, F. G. Horgan, S. Hotes, R. Jahn, I. Kühn, L. Marquez, M. Schädler, V. Tekken, D. Vetterlein, S. Villareal, C. Westphal, and M. Wiemers. 2015. Agricultural landscapes and ecosystem services in South-East Asia - the LEGATO-Project. Basic and Applied Ecology 16:661-664. http://dx.doi.org/10.1016/ j.baae.2015.10.003

Spangenberg, J. H., C. von Haaren, and J. Settele. 2014. The ecosystem service cascade: further developing the metaphor. Integrating societal processes to accommodate social processes and planning, and the case of bioenergy. Ecological Economics 104:22-32. http://dx.doi.org/10.1016/j.ecolecon.2014.04.025

Stuart, A. M., C. V. Prescott, G. R. Singleton, R. C. Joshi, and L. S. Sebastian 2007. The rodent species of the Ifugao Rice Terraces, Philippines - target or non-target species for management? International Journal of Pest Management 53(2):139-146.

Truong, V. D., C. M. Hall, and T. Garry. 2014. Tourism and poverty alleviation: perceptions and experiences of poor people in Sapa, Vietnam. Journal of Sustainable Tourism 22 (7):1071-1089. http://dx.doi.org/10.1080/09669582.2013.871019

UNESCO. 1996. Convention concerning the protection of the world cultural and natural heritage. WHC-95/CONF.203/16. World Heritage Committee, 19th session, Berlin, Germany. UNESCO, Paris, France. [online] URL: http://whc.unesco.org/archive/1995/ whc-95-conf203-16e.pdf

UNESCO. 2012. Rice terraces of the Philippine Cordilleras (Philippines) (C 722). Decision: 36 COM 7A.29. Pages 40-41 in Decisions adopted by the World Heritage Committee at its 36th session (Saint-Petersburg, 2012). WHC-12/36.COM/19. UNESCO, Paris, France. [online] URL: http://whc.unesco.org/archive/2012/ whc12-36com-19e.pdf
Van Oudenhoven, F. J. W., D. Mijatovic, and P. B. Eyzaguirre. 2011. Social-ecological indicators of resilience in agrarian and natural landscapes. Management of Environmental Quality 22 (2):154-173.

Veraart, A. J., E. J. Faassen, V. Dakos, E. H. van Nes, M. Lürling, and M. Scheffer. 2012. Corrigendum: recovery rates reflect distance to a tipping point in a living system. Nature 481 (7381):357-359. http://dx.doi.org/10.1038/nature11029

Vollmer, D., M. F. Prescott, R. Padawangi, C. Girot, and A. GrêtRegamey. 2015. Understanding the value of urban riparian corridors: considerations in planning for cultural services along an Indonesian river. Landscape and Urban Planning 138:144-154. http://dx.doi.org/10.1016/j.landurbplan.2015.02.011

Wackernagel F. W. H. 1985. Rice for the terraces: cold-tolerant varieties and other strategies for increasing rice production in the mountains of Southeast Asia. Dissertation. Cornell University, Ithaca, New York, USA.

Walker, B., C. S. Holling, S. R. Carpenter, and A. Kinzig. 2004. Resilience, adaptability and transformability in social-ecological systems. Ecology and Society 9(2):5. [online] URL: http://www. ecologyandsociety.org/vol9/iss2/art5/ 
Appendix 1. Local and scientific species names of edible plants cultivated in agoecosystems across the three study sites.

\begin{tabular}{|c|c|c|c|c|c|}
\hline & Family & Species & Local name & English name & Agroecosystem \\
\hline 1 & Amaryllidaceae & Allium ascalonicum & danggu & Shallot & $\mathrm{g}, \mathrm{p}, \mathrm{s}$ \\
\hline 2 & Amaryllidaceae & Allium sativum & amput & Garlic & $\mathrm{g}, \mathrm{p}, \mathrm{s}$ \\
\hline 3 & Amaryllidaceae & Allium сера & buyah & Onion & $\mathrm{g}, \mathrm{p}, \mathrm{s}$ \\
\hline 4 & Anacardiaceae & Mangifera indica & mangga & Mango & $\mathrm{w}$ \\
\hline 5 & Araceae & Colocasia esculenta & latud & Taro & $\mathrm{g}, \mathrm{p}, \mathrm{s}$ \\
\hline 6 & Arecaceae & Areca catechu & moma & Areca palm & $\mathrm{w}$ \\
\hline 7 & Arecaceae & Calamus manillensis & lituku & Rattan & $\mathrm{w}$ \\
\hline 8 & Arecaceae & Cocos nucifera & liyug & Coconut & $\mathrm{w}$ \\
\hline 9 & Brassicaceae & Brassica rapa & dagawan & Chinese cabbage & $\mathrm{g}, \mathrm{p}, \mathrm{s}$ \\
\hline 10 & Bromeliaceae & Ananas comosus & ga'ad & Pineapple & $\mathrm{W}$ \\
\hline 11 & Caricaceae & Carica papaya & tapaya & Papaya & $\mathrm{w}, \mathrm{s}$ \\
\hline 12 & Clusiaceae & Garcinia benthami & bulon & - & $\mathrm{w}$ \\
\hline 13 & Convolvulaceae & Ipomoeae batatas & lapne & Sweet potatoe & $\mathrm{g}, \mathrm{s}$ \\
\hline 14 & Cucurbitaceae & Cucumis sativus & ahimmun & Cucumber & $\mathrm{g}$ \\
\hline 15 & Cucurbitaceae & Cucurbita maxima & kaluhhaba & Squash & $\mathrm{g}, \mathrm{p}, \mathrm{s}$ \\
\hline 16 & Cucurbitaceae & Sechium edule & sayote & Chayote & $\mathrm{g}$ \\
\hline 17 & Cucurbitaceae & Momordica charantia & ampalaya & Bitter melon & $\mathrm{g}$ \\
\hline 18 & Dipterocarpaceae & Shorea astylosa & bultic & - & $\mathrm{w}$ \\
\hline 19 & Euphorbiaceae & Manihot esculenta & kahoy & Cassava & $\mathrm{s}$ \\
\hline 20 & Fabaceae & Arachis hypogaea & mani & Peanut tree & s \\
\hline 21 & Fabaceae & Cajanus cajan & uldih & Pigeon peas & $\mathrm{s}$ \\
\hline 22 & Fabaceae & Lablab purpureus & ittab & Hyancinth bean & $\mathrm{g}$ \\
\hline 23 & Fabaceae & Phaseolus vulgaris & puddilah & String beans & $\mathrm{g}, \mathrm{p}, \mathrm{s}$ \\
\hline 24 & Fabaceae & Vigna radiata & balatung & Mung beans & $\mathrm{s}$ \\
\hline 25 & Lamiaceae & Origanum vulgare & oregano & Oregano & $\mathrm{w}$ \\
\hline 26 & Lauraceae & Persea americana & abukadu & Avocado & $\mathrm{w}$ \\
\hline 27 & Melastomataceae & Medinilla speciosa & balangbang & $\begin{array}{l}\text { Showy asian } \\
\text { grapes }\end{array}$ & $\mathrm{w}$ \\
\hline 28 & Meliaceae & Sandoricum koetjape & santol & Santol & $\mathrm{w}$ \\
\hline 29 & Moraceae & Artocarpus heterophyllus & kakaw & Jackfruit & $\mathrm{s}$ \\
\hline 30 & Moringaceae & Moringa oleifera & malunggay & Moringa & $\mathrm{w}, \mathrm{g}$ \\
\hline 31 & Musaceae & Musa spp. & balat & Banana & $\mathrm{s}$ \\
\hline 32 & Myrtaceae & Psidium guajava & gayyabat & Guava & $\mathrm{w}$ \\
\hline 33 & Phyllanthaceae & Antidesma leptocladum & galiwgiwon & - & $\mathrm{w}$ \\
\hline 34 & Piperaceae & Piper betle & hapid & Betel & $\mathrm{w}$ \\
\hline 35 & Poaceae & Cymbopogon citratus & - & Lemon grass & $\mathrm{g}$ \\
\hline 36 & Poaceae & Oryza sativa & paye & Rice & $\mathrm{p}$ \\
\hline 36 & Poaceae & Saccharum officinarum & unah & Sugar cane & $\mathrm{w}, \mathrm{s}$ \\
\hline 37 & Poaceae & Zea mays & gahhilang & Corn & $\mathrm{g}, \mathrm{s}$ \\
\hline
\end{tabular}




\begin{tabular}{llllll}
\hline 38 & Podocarpaceae & Dacrycarpus imbricatus & gutmu & - & w \\
39 & Rosaceae & Rubus rosifolius & pinit & Roseleaf bramble & w \\
40 & Rubiaceae & Coffea sp. & kapi & Coffee & w \\
41 & Rutaceae & Citrofortunella & gugulu & Calamansi & w, s \\
42 & Rutaceae & Citrocarpa maxima & lubban & Pomelo & w \\
43 & Rutaceae & Evodia meliaefolia & galikon & - & w \\
44 & Solanaceae & Capsicum sp & paktiw & Chili & w, s \\
45 & Solanaceae & Nicotiana tobacum & taba'u & Tobacco & s \\
46 & Solanaceae & Solanum lycopersicum & kamatih & Tomatoes & g \\
47 & Solanaceae & Solanum melongena & talung & Eggplant & g, s \\
48 & Solanaceae & Solanum nigrum & amti & Black nightshade & g, s \\
49 & Verbenaceae & Premna odorata & atingol & Alagaw & w \\
50 & Zingiberaceae & Zingiber officinale & laya & Ginger & g, p, s \\
\hline
\end{tabular}

Agroecosystems are: woodlots (w), gardens (g), rice paddies (p) and swidden fields (s) 